\title{
Optimized antimicrobial and antiproliferative activities of titanate nanofibers containing silver
}

This article was published in the following Dove Press journal:

International Journal of Nanomedicine

I August 201 |

Number of times this article has been viewed

\section{Yong Hua Su* \\ Zi Fei Yin* \\ Hai Liang Xin \\ Hui Qing Zhang \\ Jia Yu Sheng \\ Yan Long Yang \\ Juan Du \\ Chang Quan Ling}

Department of Traditional Chinese Medicine, Changhai Hospital, The

Second Military Medical University,

Shanghai, People's Republic of China

*These authors contributed equally
Correspondence: Chang Quan Ling Department of Traditional Chinese Medicine, Changhai Hospital,

The Second Military Medical University, 168 Changhai Road, Shanghai, 200433

People's Republic of China

Tel +862 2। 8187 I55।

Fax $+86218187 \quad 1559$

Email lingchangquan@smmu.edu.cn

\begin{abstract}
Titanate nanofibers containing silver have been demonstrated through the experiments reported herein to have effective antifungal and antiproliferative activities in the presence of UV light. The titanate nanofibers containing silver can be fabricated by means of ion exchange followed by a topochemical process in an environment suitable for reductive reactions. Excellent antibacterial, antifungal, and antiproliferative activities could be demonstrated by both $\mathrm{Ag}_{2} \mathrm{Ti}_{5} \mathrm{O}_{11} \cdot \mathrm{xH}_{2} \mathrm{O}$ and $\mathrm{Ag} /$ titanate (UV light irradiation) due to their unique structures and compositions, which have photocatalytic activities to generate reactive oxygen species and capabilities to continuously release the silver ions. Therefore these materials have the potential to produce a membrane for the treatment of superficial malignant tumor, esophageal cancer, or cervical carcinoma. They may also hold utility if incorporated into a coating on stents in moderate and advanced stage esophageal carcinoma or for endoscopic retrograde biliary drainage. These approaches may significantly reduce infections, inhibit tumor growth, and importantly, improve quality of life and prolong survival time for patients with tumors.
\end{abstract}

Keywords: silver, titanate, photocatalytic, antiproliferative, antimicrobial

\section{Introduction}

Silver has long been known to be able to exhibit a strong toxicity to a wide spectrum of microorganisms with minimal perturbation to normal human cells. More specifically, silver ions have been revealed to be the most useful form of silver in terms of reported antibactericidal activity. ${ }^{1-5}$ Before the introduction of the modern compounds containing silver, dilute solutions of silver nitrate were adopted to treat infections as early as in the nineteenth century. Nevertheless, silver existing in this form or in an ionic state in solution is not stable because the silver ions can easily be reduced to silver clusters, which results in significant loss of their antibactericidal effects. Silver-based compounds such as sulfadiazine silver $\left(\mathrm{C}_{10} \mathrm{H}_{9} \mathrm{AgN}_{4} \mathrm{O}_{2} \mathrm{~S}\right)$ and mild silver protein (Argyrol ${ }^{\circledR}$; Argyrol Pharmaceuticals, Seattle, WA) have been used extensively in various bactericidal applications. ${ }^{6-9}$ For example, these silver-based compounds have been shown to be effective in the care of burns, severe chronic osteomyelitis, urinary tract infections, and central venous catheter infections. ${ }^{10,11}$ Because these silver-based organic compounds are quite unstable, however, especially when exposed to heat or light irradiation, controlling dosage and obtaining consistent therapeutic outcomes is very challenging. Recently, other materials containing silver, such as $\mathrm{Ag}_{2} \mathrm{~S} / \mathrm{Ag}$ heterodimers, silicon nanowires decorated with silver nanoparticles and $\mathrm{Ag} / \mathrm{SiO}_{2}$ nanocomposites, have been reported and some preliminarily antimicrobial 
activities have been demonstrated. ${ }^{12-14}$ One shortcoming of these systems relates to the relatively low concentration of silver ions present since they can be released only through the dissolution process. This is dependent on the surrounding environment and includes parameters such as $\mathrm{pH}$, temperatures, solvents, redox conditions, and ionic strength. Indeed, even the storage time of composites containing silver could influence their release rate of silver ions. ${ }^{4}$ Moreover, practical applications of various silver-based materials are often hampered by the ease of oxidation of silver nanoparticles to form silver oxide, which may cause loss of antibacterial activity. ${ }^{5}$ Therefore, it is essential to design and construct a new carrier for stable silver ions which can store and release silver ions in a controllable manner.

Protonated titanate usually has a layered atomic structure which is clearly capable of exchanging ions, especially monovalent cations such as $\mathrm{Na}^{+}, \mathrm{K}^{+}, \mathrm{Ag}^{+}$, and $\mathrm{Cs}^{+} .{ }^{15-18} \mathrm{The}$ basic framework is built up from a structure unit of four $\mathrm{TiO}_{6}$ octahedra arranged in a line by means of edge sharing. The units are combined with each other from above and below to form a zigzag string of octahedra. The formed string is then joined with other strings by corner sharing to make a staggered sheet containing 2-dimensional (2D) galleries inside. ${ }^{19}$ Titanates of this structure have very pronounced ion-exchanging properties, allowing almost stoichiometric amounts of alkaline ions to be exchanged. ${ }^{20-24}$ Due to its good biocompatibility, titanates have been used in various biological processes including biocatalysts, biosensors, controlled drug delivery, and bioscaffolds for cell cultures. ${ }^{25-29}$ Furthermore, the light irradiation can cause titanates to generate reactive oxygen species (ROS) which are capable of damaging DNA, cell membranes, and cellular proteins, ${ }^{5}$ and may lead to the death of microorganisms. The metallic silver nanoparticles growing on the surface of titanates can not only promote this photocatalytic process, but also enhance the absorption of the photons in the visible light region, to generate the ROS. The oxidation of silver nanoparticles can be avoided in the reductive chemical environment that was shaped during the photocatalytic process, thereby maintaining their antibacterial activity. By means of the above, the combination of the silver ions and the photocatalytic effects may serve to construct new functional materials for antimicrobial, antifungal, and antiproliferative applications, and potentially may also offer synergistic functions.

Herein, we report a facial synthesis process to prepare layered 1-dimensional (1D) titanates containing silver in different forms. The optimized forms of these materials were successfully screened for antimicrobial, antifungal, and antiproliferative applications. Through ion exchange and the controlled reduction processes, we demonstrate that silver species can be inserted into the layered titanates and then reduced to elemental silver nanoparticles. The average particle size and particle size distribution of silver nanoparticles can be tuned by using chemical $\left(\mathrm{NaBH}_{4}\right)$ or UV-light reduction processes. Interestingly, the experimental results indicate that silver titanate and $\mathrm{Ag} /$ titanate in the presence of UV-light irradiation have better antimicrobial, antifungal, and antiproliferative activities. These promising results indicate the synergistic effects that can be obtained through ROS being released from the photocatalysis process along with the silver ions that are released from the ionexchange process. As a semiconducting material, layered titanates play a dual role, acting as a silver ion reservoir, as well as a photocatalyst.

\section{Materials and Methods Materials}

All reagents used were of analytical grade. $\mathrm{TiF}_{4}$ and the $\mathrm{NaBH}_{4}$ were obtained from Sigma-Aldrich (St Louis, MO). All aqueous solutions were prepared with double-distilled water.

\section{Synthesis of titanates and $\mathrm{Ag} /$ titanates}

The layered protonated pentatitanate $\left(\mathrm{H}_{2} \mathrm{Ti}_{5} \mathrm{O}_{11} \cdot \mathrm{H}_{2} \mathrm{O}\right)$ was prepared according to a procedure reported previously. ${ }^{30}$ In a typical experiment, $30 \mathrm{~mL}$ of $0.040 \mathrm{M} \mathrm{TiF}_{4}$ aqueous solution containing $10 \mathrm{~g}$ of $\mathrm{NaOH}$ was kept in a Teflon-lined autoclave at $180^{\circ} \mathrm{C}$ for $48-50$ hours and then the white gellike product was washed thoroughly with a $0.50 \mathrm{M} \mathrm{HCl}$ solution and deionized water. To generate the $\mathrm{Ag} / \mathrm{titanate}$ with the $\mathrm{Ag}^{+}$nutrients from the interlayer space, typically, $0.5 \mathrm{~g}$ of white $\mathrm{H}_{2} \mathrm{Ti}_{5} \mathrm{O}_{11} \cdot \mathrm{H}_{2} \mathrm{O}$ product was added to $12.5 \mathrm{~mL}$ of $\mathrm{AgNO}_{3}$ aqueous solution with a concentration of $0.01-0.1 \mathrm{M}$ and stirred vigorously in the dark for 30-52 hours. In the wake of the $\mathrm{H}^{+} / \mathrm{Ag}^{+}$exchange, the sample was washed thoroughly with deionized water to remove externally adsorbed $\mathrm{Ag}^{+}$. Afterwards, the titanate with $\mathrm{Ag}^{+}$in the galleries was redispersed in $25 \mathrm{~mL}$ of deionized water and exposed to UV light (Xe $300 \mathrm{~W}, 320-400 \mathrm{~nm}$ ) for 8-14 hours. As a parallel reduction method, $\mathrm{NaBH}_{4}$ aqueous solution $(0.02-0.05 \mathrm{M})$ was applied and stirred vigorously for 20 minutes. After the reaction, the $\mathrm{Ag} /$ titanate nanocomposites were washed with deionized water three times. It should be noted that all the ion-exchange and redox processes were performed at room temperature. 


\section{Characterization methods}

\section{and instruments}

Scanning electron microscopy with energy-dispersive X-ray spectroscopy (SEM/EDX, JSM-5600 LV [JEOL, Tokyo, Japan]; FESEM/EDX, JSM-6700F [JEOL]) and transmission electron microscopy (TEM, JEM 2010, $200 \mathrm{kV}$ [JEOL]) were used to examine the dimension, morphology, and chemical composition of the samples. Surface binding elements were analyzed with X-ray photoelectron spectroscopy (XPS, Kratos Axis Ultra DLD, Manchester, UK). All binding energies were referenced to the $\mathrm{C} 1 \mathrm{~s}$ speak $(285.0 \mathrm{eV})$ arising from surface hydrocarbons (or possible adventitious hydrocarbon). Prior to peak deconvolution, X-ray satellites and inelastic background (Shirley-type) were subtracted for all spectra. The UV-vis absorption spectra of protonated pentatitanate, silver titanate, and $\mathrm{Ag} /$ titanate nanostructures were examined with a UV-vis spectrophotometer (Cary-500; Varian Inc, Palo Alto, CA).

\section{Antibacterial activity assay}

E. coli DH-5 $\alpha$ was selected as an indicator experimental bacteria. Luria Bertani (LB) broth was used as the culture medium. Bacteria were aerobically cultivated in LB broth for 20 hours at $37^{\circ} \mathrm{C}$. A sterile cotton swab was used to inoculate $E$. coli $\mathrm{DH}-5 \alpha$ on to the surface of LB broth plates. The titanate-based compounds $(2 \mathrm{mg})$ were suspended in sterile water and placed over the surface of the plates to keep in contact with E. coli. Each compound was divided into two groups, with one group being kept in the dark while the other was exposed to natural light for 2 hours per day. We took this approach so that the bacteria would not be killed by ultraviolet rays and the compounds could be excited by the minimal ultraviolet light present in the natural light. The diameter of inhibition zone was measured after 24 hours of incubation at $37^{\circ} \mathrm{C}$, which enabled evaluation of the antibacterial activity.

\section{Antifungal activity assay}

To assess antifungal activity, the in vitro minimal inhibitory concentrations (MICs) of the titanate-based compounds were determined by using Candida albicans strain SC5314. These yeast cells were cultivated on Yeast Extract Peptone Dextrose (YPD) medium plates at $30^{\circ} \mathrm{C}$ overnight to obtain single colonies. These single colonies were then resuspended in YPD broth to a density of $1.0 \times 10^{8}$ cells $/ \mathrm{mL}$. The MICs of the cells were determined by a microdilution test based on the macrodilution referential method of the National Committee for Clinical Laboratory Standards. ${ }^{31}$ Cells $\left(100 \mu \mathrm{L} ; 5.0 \times 10^{4}\right.$ cells $\left./ \mathrm{mL}\right)$ were then added into wells in a 96-well plate in rows A and B. Row A contained $200 \mu \mathrm{L}$ of yeast cells and the titanate-based compounds for testing, while row B contained $200 \mu \mathrm{L}$ of yeast cells only. Row C contained $200 \mu \mathrm{L}$ of RPMI 1640 medium (Gibco, Langley, OK) as a blank control while row D contained $200 \mu \mathrm{L}$ of RPMI 1640 medium, as well as titanatebased compounds. The titanate-based compounds to be tested were dispersed in phosphate buffer solution (PBS) and the two-fold serial dilutions were prepared in RPMI 1640 medium with a final concentration ranging from 200 to $0.390 \mu \mathrm{g} /$ $\mathrm{mL}$. Fluconazole (FLC) served as the positive control with final concentrations ranging between 64.0 and $0.125 \mu \mathrm{g} / \mathrm{mL}$. Each titanate-based compound was divided into two groups with one group being kept in the dark while the other was exposed to ultraviolet light ( $\lambda=365 \mathrm{~nm}$, UVA, ENF-280C/ FE, Spectroline, Westbury, NY) for 2 hours. The plates were then incubated at $30^{\circ} \mathrm{C}$ for 24 hours without being shaken and the growth of cells was determined by measuring the optical density at wavelength of $620 \mathrm{~nm}$. The $\mathrm{MIC}_{80}$ and $\mathrm{MIC}_{50}$ of the target additives (titanate-based compounds or FLC) were defined as an approximately $80 \%$ and $50 \%$ reduction in terms of the growth of cells compared with the growth of cells with no target additive.

\section{Antiproliferative activity assay}

The in vitro antiproliferative activities of protonated pentatitanate $\left(\mathrm{H}_{2} \mathrm{Ti}_{5} \mathrm{O}_{11} \cdot \mathrm{H}_{2} \mathrm{O}\right)$ and corresponding silver-containing titanate nanofibers were studied on a human liver cancer cell line (Hep G2) by employing the Alamar Blue assay. ${ }^{32,33}$ Parallel control groups without titanate-based inorganic compounds were also studied. Each titanate-based compound was further separated into two groups, with one group being kept in the dark while the other was exposed to ultraviolet light ( $\lambda=365 \mathrm{~nm}$, UVA) for 2 hours per day. Hep G2 cells were cultivated in DMEM and 10\% fetal bovine serum (FBS) at $37^{\circ} \mathrm{C}$ in $5 \% \mathrm{CO}_{2}$. Cells were then added into 96 well plates $\left(1 \times 10^{5} \mathrm{cells} / \mathrm{mL}, 100 \mu \mathrm{L}\right)$ and the medium was replaced with DMEM and $10 \%$ FBS containing titanate-based compounds 24 hours later. Titanate-based compounds were tested over concentrations ranging from $3.125 \mu \mathrm{g} / \mathrm{mL}$ to $200 \mu \mathrm{g} / \mathrm{mL}$. Then cells were incubated for 24 hours before $10 \mu \mathrm{L}$ Alamar Blue was added and the plates were then incubated in the dark for a further 4 hours. Mitomycin C (MMC) was used as positive control in the cell viability assays. The optical density was monitored at $570 \mathrm{~nm}$ (absorbance) and $630 \mathrm{~nm}$ (reference absorbance) in a microplate reader (Elx-808; Biotek, Winooski, VT). The calculated $\mathrm{IC}_{50}$ values were expressed as the concentration of titanate-based compounds 
$(\mu \mathrm{g} / \mathrm{mL})$ under which $50 \%$ of cell death was observed, compared with the controls.

\section{Results and discussion}

A series of experiments was conducted to prepare silver titanate and Ag/titanate nanocomposites with the process shown in Scheme 1. The major steps involved are: (a) initial protonated pentatitanate with ion-exchanging capabilities (idealized structure viewed in the [010] direction; open and filled red circles denote $\mathrm{H}^{+}$or $\mathrm{H}_{3} \mathrm{O}^{+}$at $\mathrm{y}=0$ and $1 / 2$, respectively); (b) replacement of proton $\mathrm{H}^{+}$by $\mathrm{Ag}^{+}$in the interlayer space (open and filled blue circles denote $\mathrm{Ag}^{+}$); and (c) partial intercalated $\mathrm{Ag}^{+}$cations were transferred to the outside of the galleries and then reduced to form silver clusters/nanoparticles by using titanates as the heterogeneous nucleation substrate. Some water molecules may also exist in the galleries in a quasi-liquid state, but these are not shown in the diagram. It should be noted that another similar process, reduction with $\mathrm{NaBH}_{4}$, can be applied to the same cations to form more, relatively large, silver nanoparticles growing on the layered substrate. The basic structure of host lamellar $\left[\mathrm{Ti}_{5} \mathrm{O}_{11}{ }^{2-}\right]_{\infty}$ does not change throughout the process from (A) to $(C)$ in Scheme 1, except that the interlayer distance may vary with the degree of cation interaction, as well as by the amount of free interlayer water introduced.

Figure 1 shows the TEM images (A-D) and corresponding digital camera photographs $(\mathrm{e}-\mathrm{h})$ of the: initial protonated

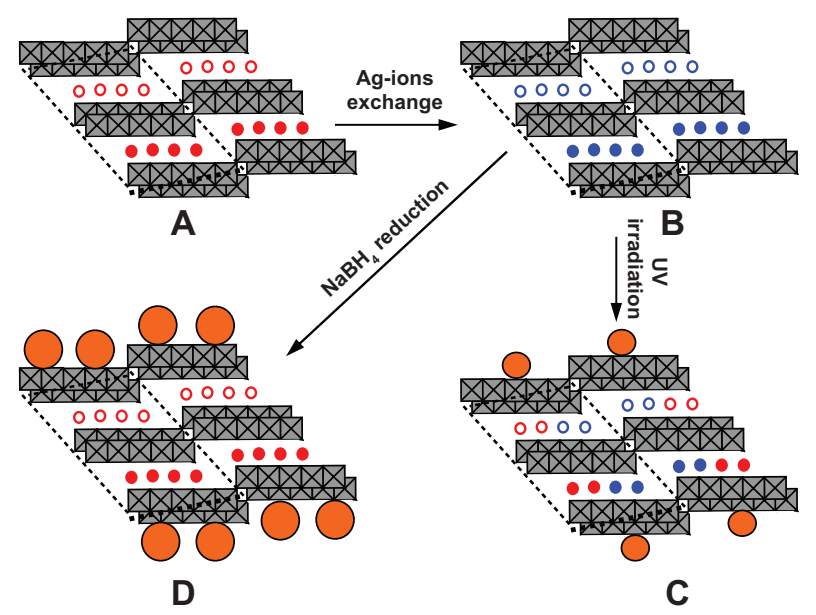

$\bigotimes=\mathrm{TiO}_{6}$ octahedra; $\bigcirc=$ Silver nanoparticles $\bullet \circ=$ hydrogen protons; $\bullet \circ=\mathrm{Ag}^{+}$

Scheme I Schematic representations of "nutrients from galleries" principle to generate $\mathrm{Ag} /$ titanate nanocomposites: (A) represents the pristine protonated pentatitanate $\left(\mathrm{H}_{2} \mathrm{Ti}_{5} \mathrm{O}_{11} \cdot \mathrm{H}_{2} \mathrm{O}\right)$; (B) silver titanate $\left(\mathrm{Ag}_{2} \mathrm{Ti}_{5} \mathrm{O}_{11} \cdot \mathrm{xH}_{2} \mathrm{O}\right)$ prepared by exchange of protons with $\mathrm{Ag}^{+}$cations; partial (C) or fully (D) $\mathrm{Ag}^{+}$cations exchange with protons in the layered space and the formation of the silver nanoparticles on titanate substrates with the redox process. The unit cell (a-d; enclosed by dotted lines) are C-based centered monoclinic, which is projected along [0 10$]$ direction. Note: Open and filled circles indicate the locations at $y=0$ and $1 / 2$, respectively.
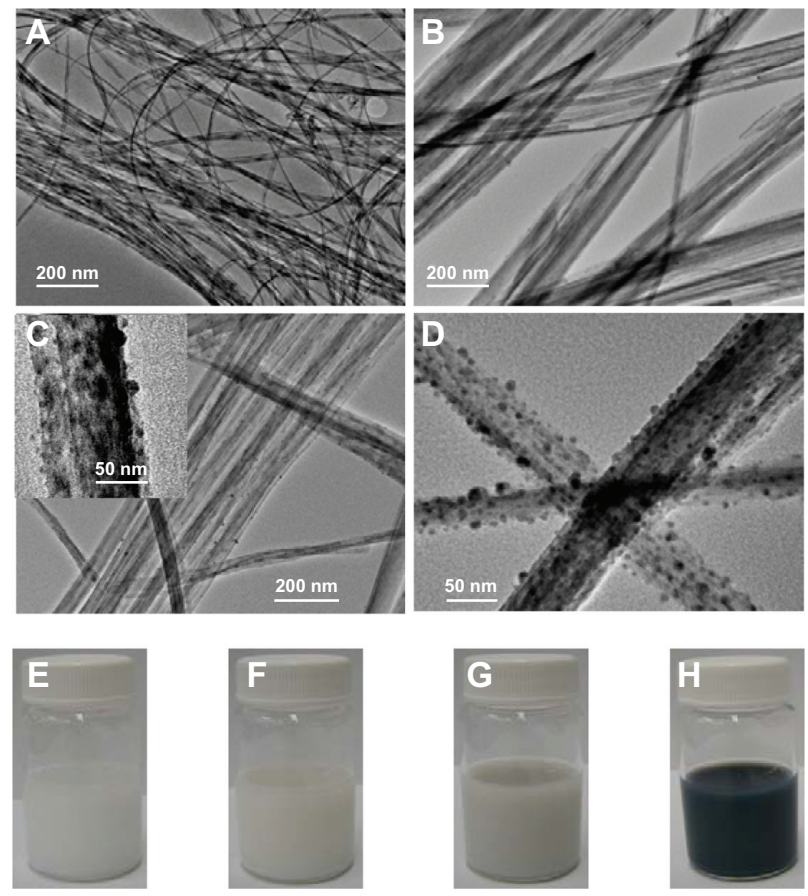

Figure I TEM images and digital camera photographs of protonated pentatitanate $\left(\mathrm{H}_{2} \mathrm{Ti}_{5} \mathrm{O}_{11} \cdot \mathrm{H}_{2} \mathrm{O}\right)(\mathbf{A}$ and $\mathbf{E})$, titanate after $\mathrm{Ag}^{+}$cations exchange (B and $\left.\mathbf{F}\right)$, partial reduction of $\mathrm{Ag}^{+}$cations from the layered space with the UV light irradiation (C and $\mathbf{G}$ ), and reduction of $\mathrm{Ag}^{+}$cations with $\mathrm{NaBH}_{4}$ agent ( $\mathbf{D}$ and $\mathbf{H}$ ).

pentatitanate $\left(\mathrm{H}_{2} \mathrm{Ti}_{5} \mathrm{O}_{11} \cdot \mathrm{H}_{2} \mathrm{O}\right)$ nanofibers as the starting structural basis (A); fully $\mathrm{Ag}^{+}$exchanged titanate (B); controlled partial reverse $\mathrm{Ag}^{+}$exchange and generation of $\mathrm{Ag}$ nanoparticles on titanate substrate through interlayer mass transfer and outside redox process in UV-light irradiation $(\mathrm{C})$; and the product of fully reverse $\mathrm{Ag}^{+}$exchange and silver nanoparticles growth (D). The detailed information on preparation, structure, and properties of pristine protonated titanate $\left(\mathrm{H}_{2} \mathrm{Ti}_{5} \mathrm{O}_{11} \cdot \mathrm{H}_{2} \mathrm{O}\right)$ was illustrated in a previous publication; the bulk product dispersed in water appears as a stable milky solution, as indicated in the digital camera image (E) ${ }^{30}$ Due to its layered structure and high ion-exchanging capability, the protonated titanate nanofibers can be used as an excellent $\mathrm{Ag}^{+}$nutrients reservoir, as well as a template for further silver nanoparticles growth.

Titanate with fully $\mathrm{Ag}^{+} / \mathrm{H}^{+}$exchange was easily prepared by dispersing $\mathrm{H}_{2} \mathrm{Ti}_{5} \mathrm{O}_{11} \cdot \mathrm{H}_{2} \mathrm{O}$ nanostructures in $\mathrm{AgNO}_{3}$ aqueous solution $(0.01-0.1 \mathrm{M})$ and stirring this vigorously in the dark for 30 hours at room temperature. The silver titanate generated maintains the original nanofiber morphology well, with a relatively clean surface, meaning that no silver nanoparticles are present at this stage (see Figure 1B). Compared with the original pure protonated titanate, the corresponding photograph of silver titanate (see Figure 1F) shows a very slight yellowness. The XPS data also support the conclusion that all of the silver is in the monovalent state (see Figure 3A). Interestingly, if 
UV-light irradiation (300 W Xe, 320-400 nm) was applied to the as-prepared silver titanate aqueous solution, the color of the silver titanate would gradually change from slightly yellow to grey within 8-14 hours, as illustrated in Figure 1G. Based on the TEM observation in Figure 1C, the change of color is mainly caused by the formation of silver nanoparticles on titanate substrate, so that we can conclude that $\mathrm{Ag}^{+}$cations should be transferred from the galleries and then reduced by UV light. In UV-light irradiation, the photocatalytic nature of layered titanate can release reducing species, according to:

$$
\begin{aligned}
& \mathrm{Ag}^{+}+{e^{-}{ }^{-} \rightarrow A g^{(0)}}^{(0)} \\
& h_{V B}{ }^{+}+\mathrm{H}_{2} \mathrm{O} \rightarrow \mathrm{H}^{+}+\mathrm{HO} \text {. }
\end{aligned}
$$

even though

$$
A g^{(0)}+h_{V B}^{+} \rightarrow A g^{+}
$$

process may also exist in the presence of oxygen. As is revealed by the TEM image in Figure 1C, silver nanoparticles randomly grow on the titanate nanofibers and are approximately $10-20 \mathrm{~nm}$ with a spherical or hemispherical morphology. The high-resolution TEM (HRTEM) image shown in Figure 2 also provides evidence of the metal silver nanoparticles deposited on the titanate substrate. Measuring the lattice fringes of the HRTEM image shows that these were spaced at $0.25 \mathrm{~nm}$ on average, which is very close to the $\{111\}$ lattice spacing of the face-centered cubic (fcc) silver crystals. Furthermore, the lattice spacing

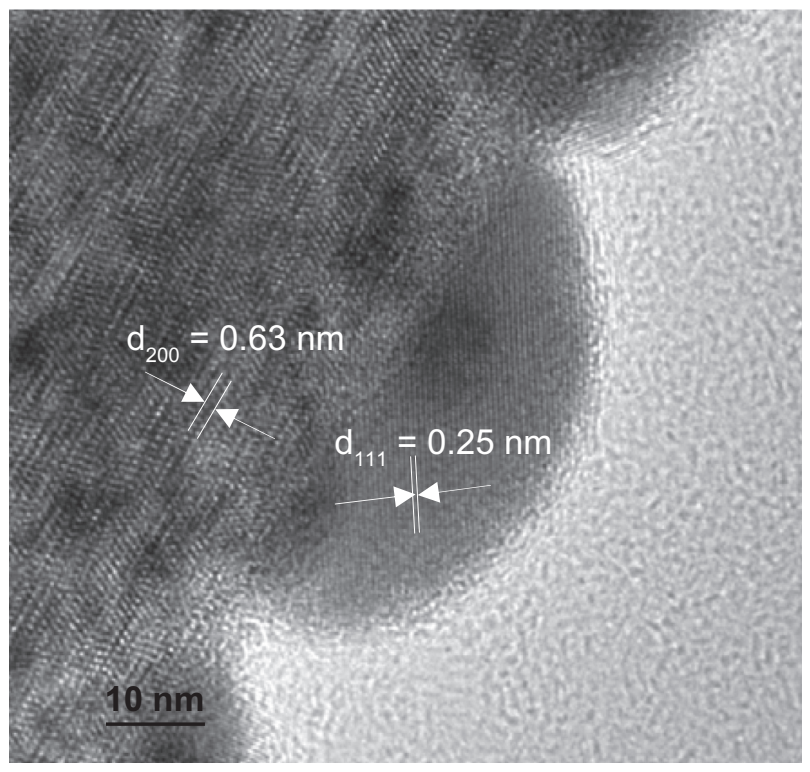

Figure 2 High resolution TEM image of $\mathrm{Ag} /$ titanate nanocomposite formed by UV light irradiation (300 W Xe, 320-400 nm). of the 1D titanate substrate is $0.63 \mathrm{~nm}$ on average (see Figure 2). Due to the meso-stable crystal structure, as well as surface properties of the titanate, zero valence silver clusters could easily form the nuclei on titanate nanofibers. Based on the TEM results (see Figure 1c), the silver ions did not penetrate too deeply into the bulk solution before they were reduced to a zero valance state, at which point they formed nanoparticles on the surface of the titanate substrate. Considering the ion balance inside the galleries, the $\mathrm{H}^{+}$or $\mathrm{H}_{3} \mathrm{O}^{+}$produced by the redox reaction could be exchanged into the galleries in the process of the reaction, resulting in distortion of titanate lattice (see Figure 2). Therefore, in the current step, the cation exchange and the redox reaction are dynamic processes. Each stage of the process could be executed in a controllable way by adjusting external parameters such as UV-light intensity or irradiation time.

$\operatorname{Ag} 3 d_{5 / 2}$

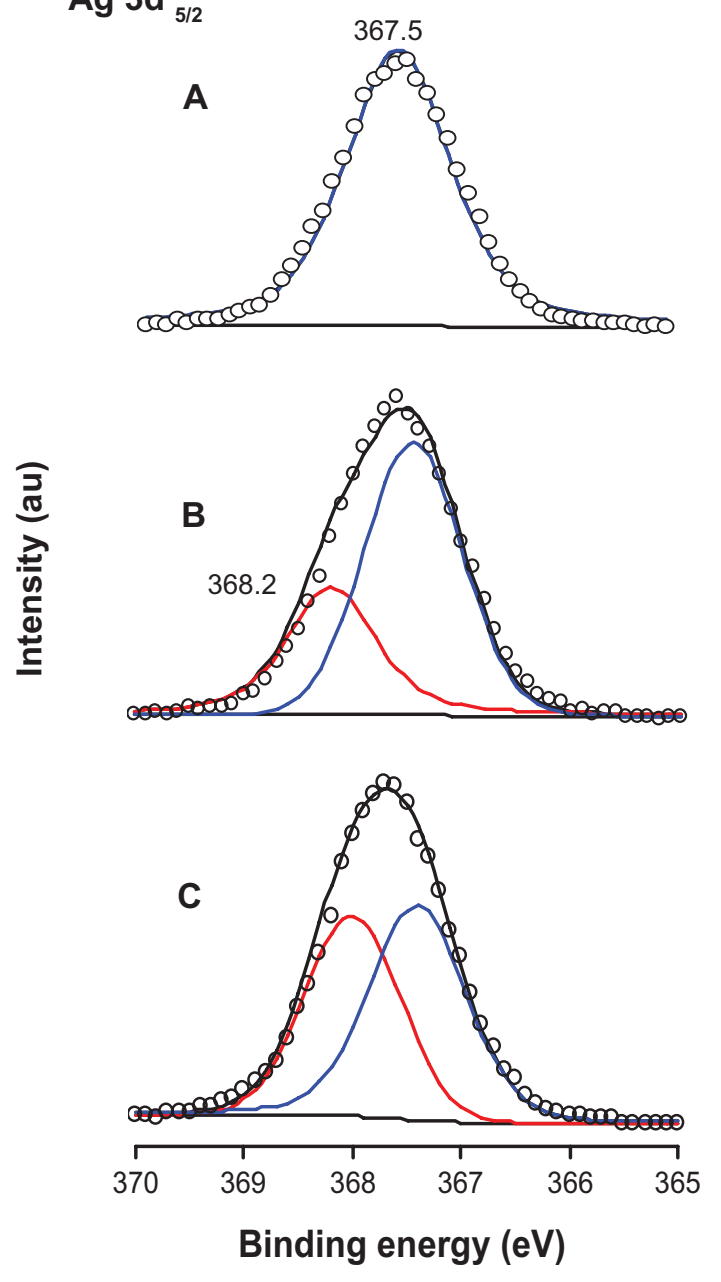

Figure $3 \mathrm{X}$-ray photoelectron spectroscopy spectra of $\mathrm{Ag} 3 \mathrm{~d}$ : (A) titanate after $\mathrm{Ag}^{+}$ cation exchange, (B) partial reduction of $\mathrm{Ag}^{+}$cations from the layered space with $\mathrm{UV}$ light irradiation, and (C) reduction of $\mathrm{Ag}^{+}$cations with $\mathrm{NaBH}_{4}$ agent. Abbreviation: au, arbitrary units. 
The XPS analysis indicates that about $34.84 \%$ of the silver cations have been reduced to a zero valence state, as shown in Figure $3 \mathrm{~b}$. Moreover, the release of $\mathrm{Ag}^{+}$nutrients from the galleries and the following redox process could be more thoroughly completed by introducing some reduction agents such as $\mathrm{NaBH}_{4}$ ( $0.05 \mathrm{M}$ in deionized water). As indicated in the TEM image (Figure 1D), a large amount of silver nanostructures was found on the titanate nanosubstrates. The color of the Ag/titanate nanocomposite at this stage has changed to black, which contributes mainly to a mass of polydispersed silver nanoparticles on the substrates (Figure 1H). Consistent with the electron microscopy image and mechanism analyses, the deconvolution of $\mathrm{Ag} 3 \mathrm{~d}_{5 / 2}$ peak indicates that $45.91 \%$ of the original silver cations have been reduced to $\mathrm{Ag}^{(0)}$, which has a typical binding energy at $368.2 \mathrm{eV}$, as depicted in Figure 3C. Accordingly, spectrophotometric measurements were also performed in order to follow the ion exchange and the reduction of $\mathrm{Ag}^{+}$. Figure 4 shows the absorbance spectra of the various titanate-based compounds, which matches well with the observations shown in Figure 1.

\section{Antimicrobial, antifungal, and antiproliferative activities}

Studies examining bacterial inhibition zones in the presence of the titanate-based compounds were performed. The results for $\mathrm{Ag} /$ titanate in the presence of $\mathrm{NaBH}_{4}$ reduction (A), Ag/titanate in the presence of UV light irradiation (B), and $\mathrm{Ag}_{2} \mathrm{Ti}_{5} \mathrm{O} 11 \cdot \mathrm{xH}_{2} \mathrm{O}$ (C), and pure $\mathrm{H}_{2} \mathrm{Ti}_{5} \mathrm{O}_{11} \cdot \mathrm{H}_{2} \mathrm{O}(\mathrm{D})$ tested against E. coli, are presented as images in Figure 5. The Ag/titanate in the presence of UV light irradiation and $\mathrm{Ag}_{2} \mathrm{Ti}_{5} \mathrm{O}_{11} \cdot \mathrm{xH}_{2} \mathrm{O}$ showed the highest antibacterial activity. The samples irradiated by the UV light have enhanced effects compared with the samples without UV

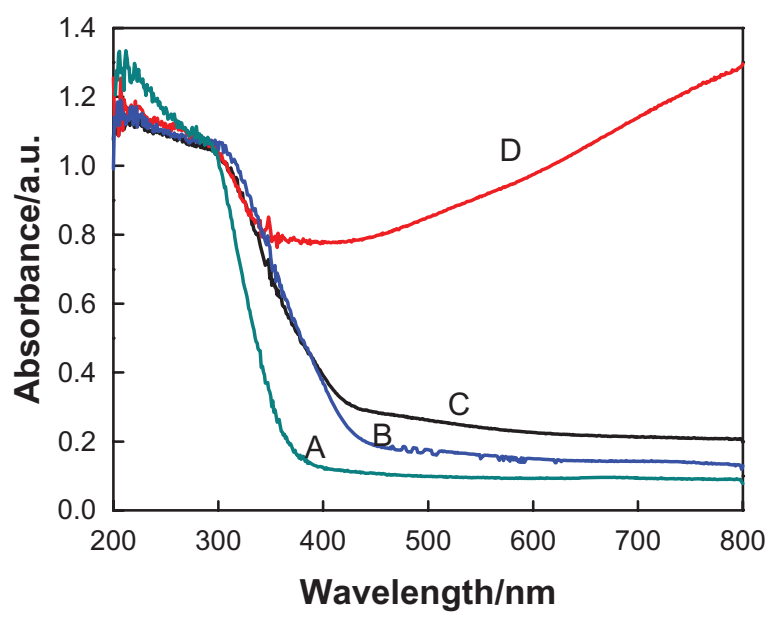

Figure 4 UV-visible absorption spectra of (A) protonated pentatitanate $\left(\mathrm{H}_{2} \mathrm{Ti}_{5} \mathrm{O}_{11} \cdot \mathrm{H}_{2} \mathrm{O}\right)$, (B) titanate after $\mathrm{Ag}^{+}$cations exchange, (C) partial reduction of $\mathrm{Ag}^{+}$cations from the layered space with the UV light irradiation, and (D) reduction of $\mathrm{Ag}^{+}$cations with $\mathrm{NaBH}_{4}$ agent.
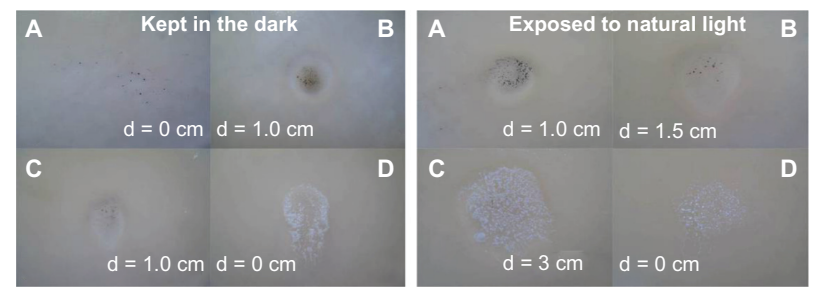

Figure 5 Comparison of the inhibition zone test for the titanate-based compounds: $\mathrm{Ag} /$ titanate by $\mathrm{NaBH}_{4}$ reduction $(\mathbf{A}), \mathrm{Ag} /$ titanate by $\mathrm{UV}$ light irradiation (B), $\mathrm{Ag}_{2} \mathrm{Ti}_{5} \mathrm{O}_{11} \cdot \times \mathrm{H}_{2} \mathrm{O}(\mathbf{C})$, and pure $\mathrm{H}_{2} \mathrm{Ti}_{5} \mathrm{O}_{11} \cdot \mathrm{H}_{2} \mathrm{O}(\mathbf{D})$.

light irradiation. The fully protonated titanate $\left(\mathrm{H}_{2} \mathrm{Ti}_{5} \mathrm{O}_{11} \cdot \mathrm{H}_{2} \mathrm{O}\right)$ nanofibers showed the least effective antibacterial activity.

The results in Figure $6 \mathrm{~A}$ show that both $\mathrm{Ag}_{2} \mathrm{Ti}_{5} \mathrm{O}_{11} \cdot \mathrm{xH}_{2} \mathrm{O}$ and $\mathrm{Ag} /$ titanate (UV light irradiation) have excellent antifungal activity, as is revealed by the $\mathrm{MIC}_{50}$ values. For all titanate compounds containing silver, UV light irradiation can significantly enhance the antifungal activity. The $\mathrm{MIC}_{50}$ values of the samples irradiated by UV light are at least two-fold lower than those of the samples without UV light irradiation. The less than ideal antifungal activity of Ag/titanate $\left(\mathrm{NaBH}_{4}\right.$ reduction) might be due to the existence of fewer silver ions between the layers of the titanate nanofibers and the relatively large size of the silver nanoparticles decorating

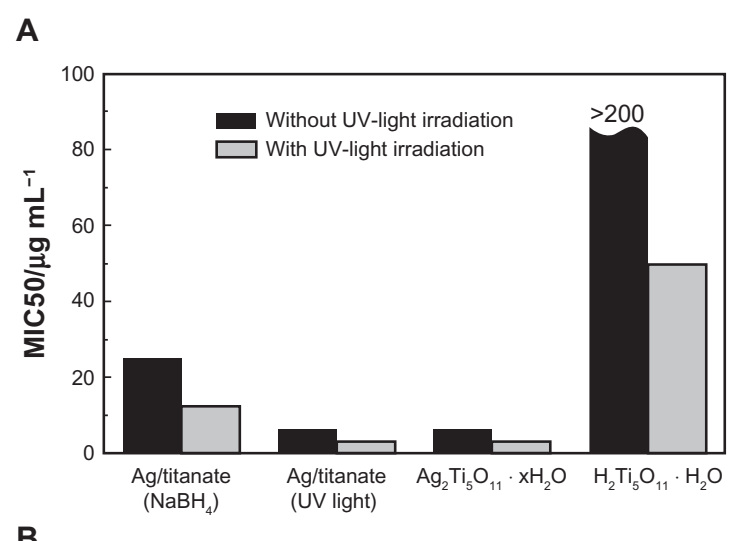

B

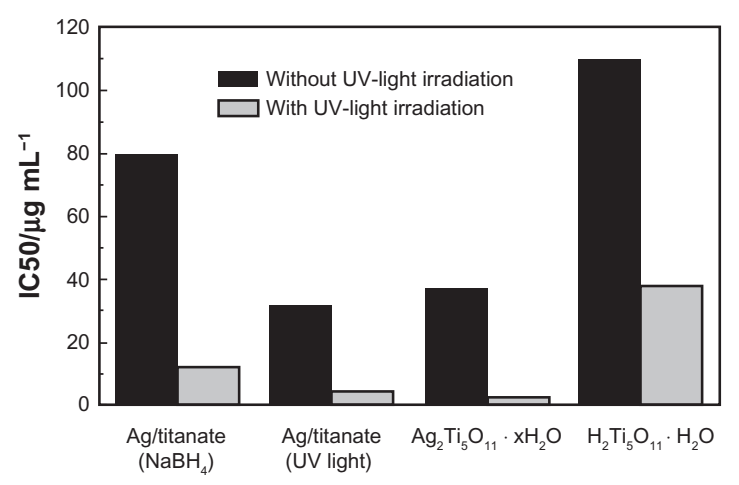

Figure 6 Antifungal (A) and antiproliferative (B) activities of titanate-based compounds, which are $\mathrm{Ag} /$ titanate by $\mathrm{NaBH}_{4}$ reduction, $\mathrm{Ag} /$ titanate by $\mathrm{UV}$ light irradiation, $\mathrm{Ag}_{2} \mathrm{Ti}_{5} \mathrm{O}_{11} \cdot \mathrm{xH}_{2} \mathrm{O}$, and pure $\mathrm{H}_{2} \mathrm{Ti}_{5} \mathrm{O}_{11} \cdot \mathrm{H}_{2} \mathrm{O}$. 
the surface. As a control sample, the fully protonated titanate $\left(\mathrm{H}_{2} \mathrm{Ti}_{5} \mathrm{O}_{11} \cdot \mathrm{H}_{2} \mathrm{O}\right)$ nanofibers show the worst antifungal activity, as expected, due to its low photocatalytic property and the absence of the silver ions. It should be noted that even though the FLC drug has the lowest $\mathrm{MIC}_{50}$ values $(0.25 \mu \mathrm{g} / \mathrm{mL}$ respectively) in the presence of UV light irradiation, it is a small organic molecule and has undesirable effects including induction of drug resistance and instability. In view of this, the titanate nanofibers containing silver developed through the process reported here are still highly attractive and have no associated antimicrobial resistance issues as they are in a purely inorganic phase and have a totally different mechanism underpinning their antifungal activity.

Silver ions can readily deactivate bacteria by reacting with the thiol functional groups in proteases, which causes loss of integrity of the membrane, and then leads to malfunction of the permeability barrier. ${ }^{5}$ This ultimately leads to the collapse of the bacterial membrane and the death of microorganisms. Furthermore, just like traditional photosensitizers, which have been widely applied in photodynamic therapy, titanate containing silver can also release highly reactive ROS to incapacitate the bacteria as well. For titanate nanofibers containing silver, the prolonged time of UV light irradiation may cause the formation of more silver nanoparticles on the surface of titanate nanofibers. However, this effect has been shown to be insignificant due to the relatively slow reduction process induced by UV light, which usually takes more than 10 hours. More interestingly, the as-prepared titanate nanocomposites containing silver also demonstrated good antiproliferative activities when tested in the human liver cancer cell line Hep G2 as a model target. As indicated in Figure 6B, both $\mathrm{Ag}_{2} \mathrm{Ti}_{5} \mathrm{O}_{11} \cdot \mathrm{xH}_{2} \mathrm{O}$ and $\mathrm{Ag} /$ titanate (UV light irradiation) have better antiproliferative effects than those observed with $\mathrm{Ag}$ /titanate $\left(\mathrm{NaBH}_{4}\right.$ reduction $)$ and plain titanate nanofibers, with the $\mathrm{IC}_{50}$ values being 32.28 and $37.51 \mu \mathrm{g} / \mathrm{mL}$, respectively, without UV light irradiation. Moreover, the $\mathrm{IC}_{50}$ values can be further lowered to 4.79 and $2.53 \mu \mathrm{g} / \mathrm{mL}$ due to ROS-mediated cell damage; this is consistent with the antifungal activities discussed above. These promising antiproliferative activities of the inorganic titanates containing silver are also comparable to those found with purely organic drugs such as mitomycin $\mathrm{C}\left(\mathrm{MMC}, \mathrm{C}_{15} \mathrm{H}_{18} \mathrm{~N}_{4} \mathrm{O}_{5}\right)$; the $\mathrm{IC}_{50}$ values were $10.16 \mu \mathrm{g} / \mathrm{mL}$ (with UV light irradiation) and $12.21 \mu \mathrm{g} / \mathrm{mL}$ (without UV light irradiation), respectively.

The titanates containing silver developed in the process reported here appear to be quite unique, with the layered titanates having at least three functions: (i) acting as a reservoir for silver ions, which can be released continuously through the ion-exchange process; (ii) stabilizing the silver nanoparticles through the formation of silver-titanate nanocomposites; and (iii) generating ROS through the photocatalytic process, which can not only effectively enhance the antibacterial, antifungal, and antiproliferative activities, but also provide an environmentally friendly approach to in situ production of silver nanoparticles and avoid the oxidation of the silver species.

\section{Conclusion}

In conclusion, a series of titanate nanostructures containing silver with tailored compositions was successfully prepared through the ion-exchange method and controlled topochemical processes described, while their antibacterial, antifungal, and antiproliferative activities have been investigated in vitro. From the results, both $\mathrm{Ag}_{2} \mathrm{Ti}_{5} \mathrm{O}_{11} \cdot \mathrm{xH}_{2} \mathrm{O}$ and $\mathrm{Ag} /$ titanate (UV light irradiation) have demonstrated excellent antibacterial, antifungal, and antiproliferative functional activities due to their unique structures and compositions, which include having photocatalytic activity to generate ROS and the ability to release silver ions continuously.

The soft chemistry strategy adopted in this working process may pave the way for the development of highly efficient, lowcost, and stable antimicrobial and antiproliferative agents with promise in applications such as producing a membrane for the treatment of superficial malignant tumors, esophageal cancer, or cervical carcinoma, and so on. They may also hold utility if incorporated into a coat on stents in moderate and advanced stage esophageal carcinoma or stents for endoscopic retrograde biliary drainage. These approaches may significantly reduce infections, inhibit tumor growth and, importantly, improve quality of life, and prolong survival time for patients with tumors.

\section{Acknowledgments}

This work was financially supported by the National Natural Science Foundation of China (No. 30672569, 30810103910). The authors wish to extend their appreciation to Professor Zee Upton, Institute of Health and Biomedical Innovation, Queensland University of Technology and Geng Li, College of the International Exchange, the Second Military Medical University, for their kind help in language editing.

\section{Disclosure}

The authors have no conflicts of interest to disclose in this work.

\section{References}

1. Chambers CW, Proctor CM, Kabler PW. Bactericidal effect of low concentrations of silver. J Am Water Works Assoc. 1962;54:208-216.

2. Russell AD, Huguo WB. Antimicrobial activity and action of silver. Prog Med Chem. 1994;31:351-370. 
3. Applerot G, Lipovsky A, Dror R, et al. Enhanced antibacterial activity of nanocrystalline $\mathrm{ZnO}$ due to increased ROS-mediated cell injury. Adv Funct Mater. 2009;19:842-852.

4. Kittler S, Greulich C, Diendorf J, Köller M, Epple M. Toxicity of silver nanoparticles increases during storage because of slow dissolution under release of silver ions. Chem Mater. 2010;22:4548-4554.

5. Crespo-Monteiro N, Destouches N, Bois L, Chassagneux F, Reynaud S, Fournel T. Reversible and irreversible laser microinscription on silvercontaining mesoporous titania films. Adv Mater. 2010;22:3166-3170.

6. Bragg PD, Rainnie DJ. The effect of silver ions on the respiratory chain of Escherichia coli. Can J Microbiol. 1974;20:883-889.

7. Banerjee M, Mallick S, Paul A, Chattopadhyay A, Ghosh SS. Heightened reactive oxygen species generation in the antimicrobial activity of a three component iodinated chitosan-silver nanoparticle composite. Langmuir. 2010;26:5901-5908.

8. Mao JY, Belcher AM, VanVliet KJ. Genetically engineered phage fibers and coatings for antibacterial applications. Adv Funct Mater. 2010;20:209-214.

9. Shang L, Li BJ, Dong WJ, et al. Heteronanostructure of Ag particle on titanate nanowire membrane with enhanced photocatalytic properties and bactericidal activities. J Hazard Mater. 2010;178:1109-1114.

10. McDonnell G, Russell AD. Antiseptics and disinfectants: activity, action, and resistance. Clin Microbiol Rev. 1999;12:147-179.

11. Grippaudo FR, Carini L, Baldini R. Procutase versus 1\% silver sulphadiazine in the treatment of minor burns. Burns. 2010;36:871-875.

12. Liong M, France B, Bradley KA, Zink JI. Antimicrobial activity of silver nanocrystals encapsulated in mesoporous silica nanoparticles. Adv Mater. 2009;21:1684-1689.

13. Pang ML, Hu JY, Zeng HC. Synthesis, morphological control, and antibacterial properties of hollow/solid $\mathrm{Ag}_{2} \mathrm{~S} / \mathrm{Ag}$ heterodimers. $\mathrm{J} \mathrm{Am}$ Chem Soc. 2010;132:10771-10785.

14. Lv M, Su S, He Y, et al. Long-term antimicrobial effect of silicon nanowires decorated with silver nanoparticles. Adv Mater. 2010;22: 5473-5467.

15. Sasaki T, Komatsu Y, Fujiki Y. Protonated pentatitanate: preparation, characterizations, and cation intercalation. Chem Mater. 1992;4:894-899.

16. Bavykin DV, Friedrich JM, Walsh FC. Protonated titanates and $\mathrm{TiO}_{2}$ nanostructured materials: synthesis, properties, and applications. $A d v$ Mater. 2006;18:807-2824.

17. Cesano F, Bertarione S, Uddin MJ, Agostini G, Scarano D, Zecchina A. Designing $\mathrm{TiO}_{2}$ based nanostructures by control of surface morphology of pure and silver loaded titanate nanotubes. J Phys Chem C. 2010;114: 169-178.

18. Li QY, Kako T, Ye JH. Strong adsorption and effective photocatalytic activities of one-dimensional nano-structured silver titanates. Appl Cata A: Gen. 2010;375:85-91.
19. Sasaki T, Watanabe M, Komatsu Y, Fujiki Y. Layered hydrous titanium dioxide: potassium ion exchange and structural characterization. Inorg Chem. 1985;24:2265-2271.

20. Sun XM, Li YD. Synthesis and characterization of ion-exchangeable titanate nanotubes. Chem Eur J. 2003;9:2229-2238.

21. Morgado EJ, Abreu MAS, Moure GT, Marinkovic BA, Jardim PM, Araujo AS. Characterization of nanostructured titanates obtained by alkali treatment of $\mathrm{TiO}_{2}$-anatases with distinct crystal sizes. Chem Mater. 2007;19:665-676.

22. Bavykin DV, Walsh FC. Kinetics of Alkali metal ion exchange into nanotubular and nanofibrous titanates. J Phys Chem C. 2007;111: 14644-14651.

23. Inoue $\mathrm{Y}$, Uota $\mathrm{M}$, Torikai $\mathrm{T}$, et al. Antibacterial properties of nanostructured silver titanate thin films formed on a titanium plate. J Biomed Mater Res A. 2010;92A:1171-1180.

24. Ma RZ, Sasaki T, BandoY. Layer-by-Layer assembled multilayer films of titanate nanotubes, Ag- or Au-loaded nanotubes, and nanotubes/ nanosheets with polycations. J Am Chem Soc. 2004;126:10382-10388.

25. Su YH, Qiao SZ, Yang HG, et al. Titanate-silica mesostructured nanocables: synthesis, structural analysis and biomedical applications. Nanotechnology. 2010;21:065604.

26. Wang QG, Gao QM, Shi JL. Enhanced catalytic activity of hemoglobin in organic solvents by layered titanate immobilization. J Am Chem Soc. 2004;126:14346-14347.

27. Dai H, Chi YW, Wu XP, Wang YM, Wei MD, Chen GN. Biocompatible electrochemiluminescent biosensor for choline based on enzyme/ titanate/chitosan composite modified electrode. Biosens Bioelectron. 2010;25:1414-1419.

28. Dong WJ, Zhang TR, Epstein J, et al. Multifunctional nanowire bioscaffolds on titanium. Chem Mater. 2007;19:4454-4459.

29. Wataha JC, Hobbs DT, Lockwood PE, et al. Peroxotitanates for biodelivery of metals. J Biomed Mater Res B. 2009;91:489-496.

30. Yang HG, Zeng HC. Synthetic architectures of $\mathrm{TiO}_{2} / \mathrm{H}_{2} \mathrm{Ti}_{5} \mathrm{O}_{11} \cdot \mathrm{H}_{2} \mathrm{O}$, $\mathrm{ZnO} / \mathrm{H}_{2} \mathrm{Ti}_{5} \mathrm{O}_{11} \cdot \mathrm{H}_{2} \mathrm{O}, \mathrm{ZnO} / \mathrm{TiO}_{2} / \mathrm{H}_{2} \mathrm{Ti}_{5} \mathrm{O}_{11} \cdot \mathrm{H}_{2} \mathrm{O}$ and $\mathrm{ZnO} / \mathrm{TiO}_{2}$ nanocomposites. J Am Chem Soc. 2005;127:270-278.

31. Nakamura K, Niimi M, Niimi K, et al. Functional expression of Candida albicans drug efflux pump Cdr1p in a Saccharomyces cerevisiae strain deficient in membrane transporters. Antimicrob Agents Chemother. 2001;45:3366-3374.

32. Gu W, Han KQ, Su YH, Huang XQ, Ling CQ. Inhibition action of bufalin on human transplanted hepatocellular tumor and its effects on expressions of Bcl-2 and Bax proteins in nude mice. J Chin Integr Med. 2007;5:155-159.

33. Ling CQ, Su YH. Possibility and necessity of constructing new nanoformula systems of traditional Chinese medicine. J Chin Integr Med. 2010;8:101-105.
International Journal of Nanomedicine

\section{Publish your work in this journal}

The International Journal of Nanomedicine is an international, peerreviewed journal focusing on the application of nanotechnology in diagnostics, therapeutics, and drug delivery systems throughout the biomedical field. This journal is indexed on PubMed Central, MedLine, CAS, SciSearch $\AA$, Current Contents ${ }^{\circledR} /$ Clinical Medicine,

\section{Dovepress}

Journal Citation Reports/Science Edition, EMBase, Scopus and the Elsevier Bibliographic databases. The manuscript management system is completely online and includes a very quick and fair peer-review system, which is all easy to use. Visit http://www.dovepress.com/ testimonials.php to read real quotes from published authors. 